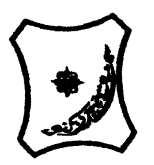

Bayero Journal of Pure and Applied Sciences, 13(1): 158 - 163

Received: March, 2020

Accepted: May, 2020

ISSN $2006-6996$

\title{
PREPARATION OF ACTIVATED CARBON FROM Syzygiumcumini SEED FOR THE REMOVAL OF CHROMIUM (II) ION FROM AQUEOUS SOLUTION
}

Yusuf, J., Muhammed, M., and Grace, B. T.

Department of Applied Chemistry Kaduna Polytechnic, Kaduna Nigeria

Corresponding Author: James Yusuf

E-mail: jamesyusuf87@yahoo.com

Phone No. 08089902063

\begin{abstract}
The most effective and low cost adsorbent produced from biomass materials is to adsorb heavy metal ions from aqueous solutions. The study aimed at utilizing chemically activated carbon from Syzygiumcumini seed plant for adsorption of chromium (II) ion from aqueous solution. The chemically produced Syzygiumcumini seed activated carbon using phosphoric acid $\left(\mathrm{H}_{3} \mathrm{PO}_{4}\right)$ was characterized using Fourier Transform Infrared Spectroscopy and Scanning Electron Microscope for its functional groups and morphology respectively. Batch adsorption was investigated to determine the optimum parameters such as $\mathrm{pH}$, adsorbent dosage, and initial concentration and contact time of the produced activated carbon from the seed plant. The optimum adsorption was observed at contact time of 60 min, dosage of $1 \mathrm{~g}$ and $\mathrm{pH}$ of 9 . The result of the research shows that Syzygiumcumini seed plant has promising percentage removal of Chromium (II) ion from aqueous solution.
\end{abstract}

Keywords: Activated carbon, $\mathrm{pH}$, Syzygium, $\mathrm{H}_{3} \mathrm{PO}_{4}$, Chromium (II) ion

\section{INTRODUCTION}

Industrialization is the major source of inclusion of heavy metals ions into the environment especially water bodies all over the world. It is well known that heavy metals such as chromium (II) ion amongst others can cause serious damages to the nerves, liver and bones (Nourbaksh et al., 2005). Also, acute systemic poisoning can result from high exposure to hexavalent chromium (Ulmanu et al., 2003). The presence of chromium (II) ion in surface and ground water is very hazardous to the environment due to its high potentiality in contaminating drinking water sources. Therefore, the use of activated carbon produced from local sources such as plant materials will be of help in removing these heavy metals from water bodies.

Activated carbon also called activated charcoal is a form of carbon processed to have small low- volume pores that increases the surface area available for adsorption or chemical reaction. Activated carbon is sometimes substituted with active due to its high degree of micro-porosity, one gram of activated carbon has a surface area in excess of $3.00 \mathrm{~m}$ as determined by gas adsorption (Bailey et al., 1999). A variety of activated carbons are commercially available but very few of them are selective for heavy metals and most of them are very costly (Mohan et al., 2005).

Black plum (Syzygiumcumini)isa plant that originated from India, it is widely used by people to treat diarrhea, inflammation and diabetes (American Diabetes Association, 2009). The seed of Syzygiumcumini are moderately rich in protein $(6.3-8.5 \%)$ and various phytochemicals along with flavonoids quercetin and rutin a well known antioxidants (Ranjan et al., 2011). 

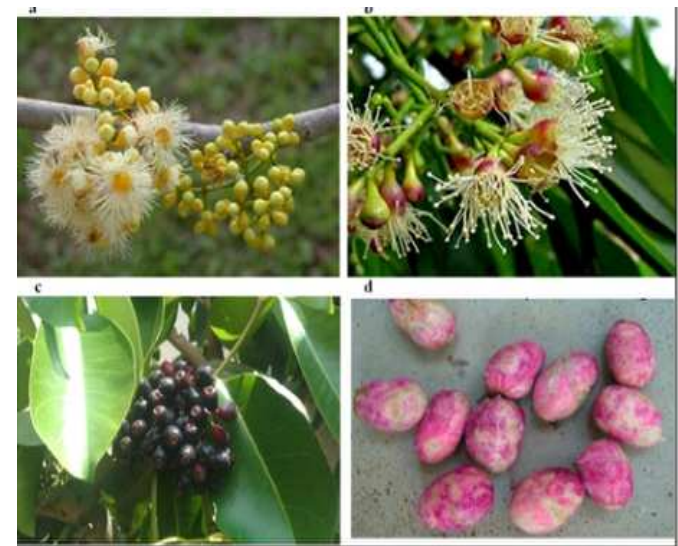

g. 1: Black plum before crushing

Adsorption is an effective and friendly method for removing both organic and inorganic pollutants from waste water. This solves the problems of sludge disposal and renders the system more economically viable, especially if low cost adsorbents are used (Ovasifet al., 2013). Therefore, this paper aimed at studying the potential of chemically produced activated carbon from black plum for waste water treatment.

\section{MATERIALS AND METHOD \\ Sample Collection}

The samples of black plum were collected fromOkehiLocal Government Area of Kogi State, Nigeria.

\section{Sample Preparation}

The collected samples were washed with distilled water and air dried at room temperature in the laboratory. Thereafter, the samples were oven dried at $110^{\circ} \mathrm{C}$ for 24 hours, after which they were pulverized into fine powdered form using grinding machine at a frequency of $35.4 \mathrm{HZ}$ for one hour. The samples were sieved using a standard sieve size of $125 \mathrm{~m}$ shaken by a sieve shaker for 20 minutes. The sieved samples were then used for the preparation of activated carbon.

\section{Production of Activated Carbon}

The one step pyrolysis method was used in preparing activated carbon. Exactly, $30 \mathrm{~g}$ of

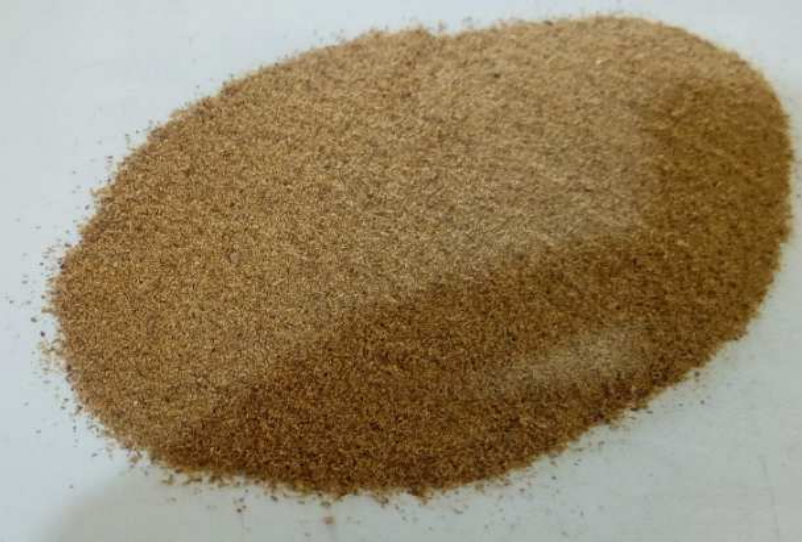

Fig. 2: After crushing

the sample was weighed for the first part on an electronic Ohaus weighing balance and poured into the crucibles. The initial weight of the crucible and crucible with samples was taken. $10 \%$ of phosphoric acid was added to the sample that's $50 \mathrm{ml}$ of phosphoric acid onto $50 \mathrm{~g}$ of the sample in a crucible. The impregnated sample was dried with the aid of an oven at $110^{\circ} \mathrm{C}$ for one hour and then was transferred to a muffle furnace maintained at $500^{\circ} \mathrm{C}$ for carbonization. The hot crucible with the carbonized sample was removed from the muffle furnace and was allowed to cool in a desiccator. The pyrolysed carbons was leeched with $2 \%$ hydrochloric acid for one hour and was washed several times with distilled water to remove the ash, residual $\mathrm{H}_{3} \mathrm{PO}_{4}$ and $\mathrm{HCl}$ from the prepared carbon until it was neutral (Dada et al., 2012). The wash carbon collected was dried in an oven at $110^{\circ} \mathrm{C}$ for two hours. The weight of the activated carbon was noted after activation to estimate the loss in weight after carbonization. The dried activated carbon was weighed to get the percentage yield and it was stored in an airtight plastic sample bottle to prevent adsorption of dust and other particles from the atmosphere. 


\section{(1)}

Where: $Y C=$ the percentage yield of carbon.

$\mathrm{W}_{\mathrm{f}}=$ the weight of carbon after activation.

$\mathrm{W}_{\mathrm{i}}=$ the weight of carbon before activation.

Characterization of the Activated Carbon.

Scanning Electron Microscopy (SEM)

Exactly, $1 \mathrm{~g}$ of the activated carbon was coated with gold at $1 \mathrm{~mm}$ for 1 second to make it electrically conductive. The sample was then glued into an aluminum pin type sample holder designed for high resolution $(\leq 17 \mathrm{~nm})$ and placed at $2 \mathrm{~mm}$ working distance. The sample holder was placed in a chamber where it is irradiated with an acceleration voltage of $15 \mathrm{KV}$. The electrons released were detected by the Back Scattered Detector full (BSD full). The BSD full then transmitted the electrons current onto another detector on a monitor mounted PC.

\section{Batch Adsorption Experiment}

The batch adsorption was carried out by varying the dosage from 0.25 to $1.25 \mathrm{~g}$ per $50 \mathrm{~mL}$ of $100 \mathrm{ppm} \mathrm{Cr}$ (II) and all the samples were mechanically agitated at 250rpm for different experiments carried out under room temperature. The adsorbent was filtered using whatman filter paper and the filterate was taking for analysis using Atomic Adsorption Spectrophotometer (AAS). The effect of $\mathrm{pH}$, the effect of adsorbent dosage, effect of the contact time duration were measured in the same manner. The removal percentage $(\% R)$ of chromium (II) ion was measured using the following formula:

$$
\% R=\frac{C_{1}-C_{2}}{C_{1}} \times 10
$$

\section{Equation(2)}

Where: $C_{1}=$ Initial Concentration of Chromium (ii) Ion in the Solution. $\mathrm{C}_{2}=$ Final Concentration of Chromium (ii) Ion in the Solution. $(\% \mathrm{R})=$ Removal Percentage

\section{RESULTS AND DISCUSSION}

The result of the activated carbon using $\mathrm{H}_{3} \mathrm{PO}_{4}$ showedtwelve elements on the activated carbon and is only the carbon that has highest elemental composition as shown in table $\mathbf{3 . 1}$ below:

Table 3.1:Result of Scanning Electron Microscope of ASCS using $\mathrm{H}_{3} \mathrm{PO}_{4}$

\begin{tabular}{cccc}
\hline S/No & Element Name & $\begin{array}{c}\text { Atomic Conc. } \\
(\mathbf{m g} / \mathbf{L})\end{array}$ & $\begin{array}{c}\text { Weight Conc. } \\
(\mathbf{m g} / \mathbf{L})\end{array}$ \\
\hline 1 & Carbon & 95.37 & 91.75 \\
2 & Oxygen & 2.24 & 2.87 \\
3 & Phosphorus & 0.41 & 1.02 \\
4 & Sodium & 0.44 & 0.81 \\
5 & Calcium & 0.19 & 0.63 \\
6 & Sulfur & 0.23 & 0.59 \\
7 & Silicon & 0.25 & 0.55 \\
8 & Magnesium & 0.25 & 0.49 \\
9 & Aluminum & 0.21 & 0.45 \\
10 & Chlorine & 0.15 & 0.42 \\
11 & Nitrogen & 0.20 & 0.23 \\
12 & Potassium & 0.06 & 0.19 \\
\hline
\end{tabular}

KEYS: ASCS Activated Syzgiumcumini Seed 
The result of Scanning electron uniform agglomeration with the average microscope (SEM) for morphology of the range of particle size distribution of black plum (Syzygiumcumini) seed using 100pm at a magnification of 537 and phosphoric acid activationwas mainly 269* as in fig. 3 below:

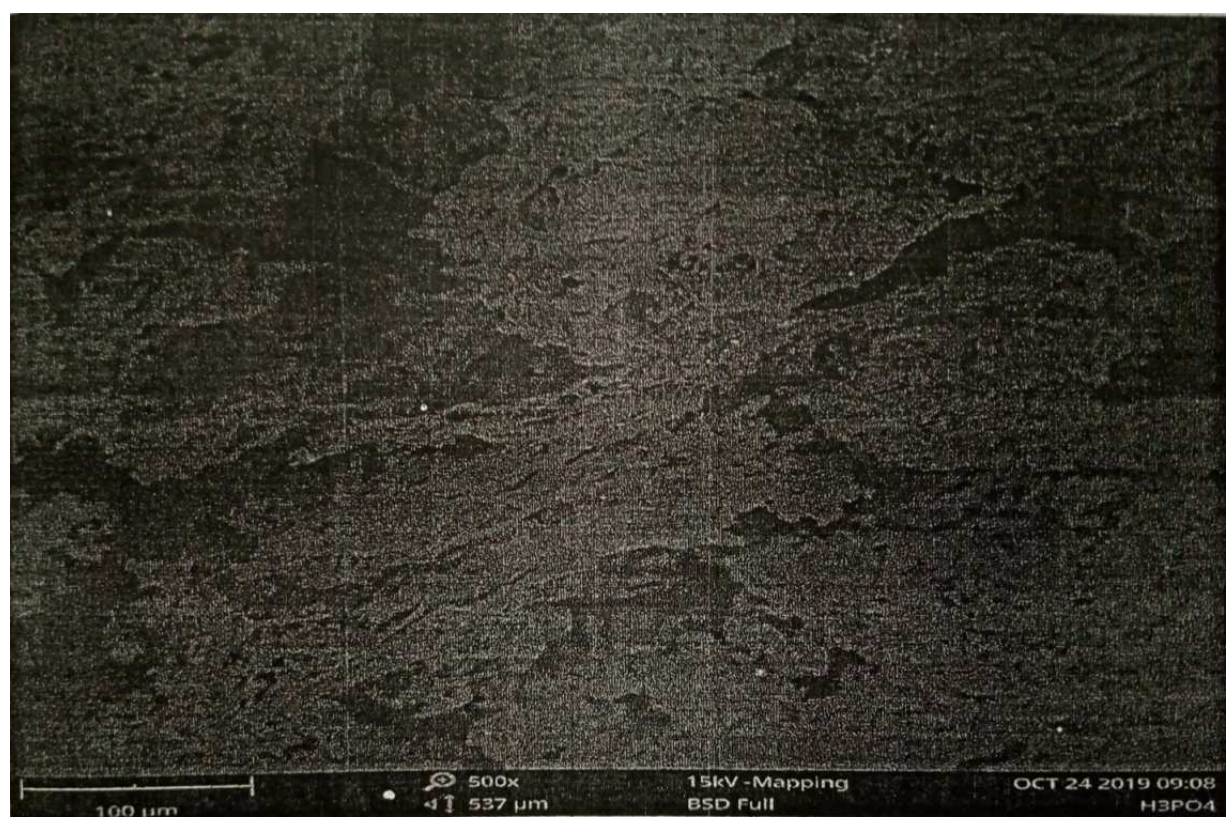

Figure 1: Scanning Electron Microscope of ASCS at $537 \mu \mathrm{m}$

Fig. 3: Scanning electron microscope of the activated Syzgiumcumini Seed

The FTIR analysis permitted bonded groups of the alkanes. The peak of Spectrophotometer observation of $1635.69 \mathrm{~cm}^{-1}$ is attributed to $\mathrm{N}-\mathrm{H}$ which Syzgiumcumini Seed in range of 4000 - indicate the presence of primary amines, $500 \mathrm{~cm}^{-1}$ and serve as a direct means for the the peak of 1277.06 is attributed to C-X identification of the surface functional indicate the presence of alkyl halides and groups as shown in table 3.2. The intensity lastly the peak of 1033.88 is attributed to of the peak decrease with increasing $\mathrm{C}-\mathrm{O}$ indicate the presence of alcohol on the activation temperature. The position of functional group. $2955.04-1465.95$ for ASCS is due to $\mathrm{C}-\mathrm{H}$

Table 3.2:Result of Fourier Transform Infrared Spectroscopy of ASCS using $\mathrm{H}_{3} \mathrm{PO}_{4}$

\begin{tabular}{cccc}
\hline S/No & Peaks $\left(\mathrm{cm}^{1}\right)$ & Bond & $\begin{array}{c}\text { Functional } \\
\text { Group }\end{array}$ \\
\hline 1 & 2955.04 & $\mathrm{C}-\mathrm{H}$ & Alkanes \\
2 & 1635.69 & $\mathrm{~N}-\mathrm{H}$ & $1^{0}$ Amine \\
3 & 1465.95 & $\mathrm{C}-\mathrm{H}$ & Alkanes \\
4 & 1273.06 & $\mathrm{C}-\mathrm{X}$ & Alkyl halides \\
5 & 1033.88 & $\mathrm{C}-\mathrm{O}$ & Alcohol \\
\hline
\end{tabular}




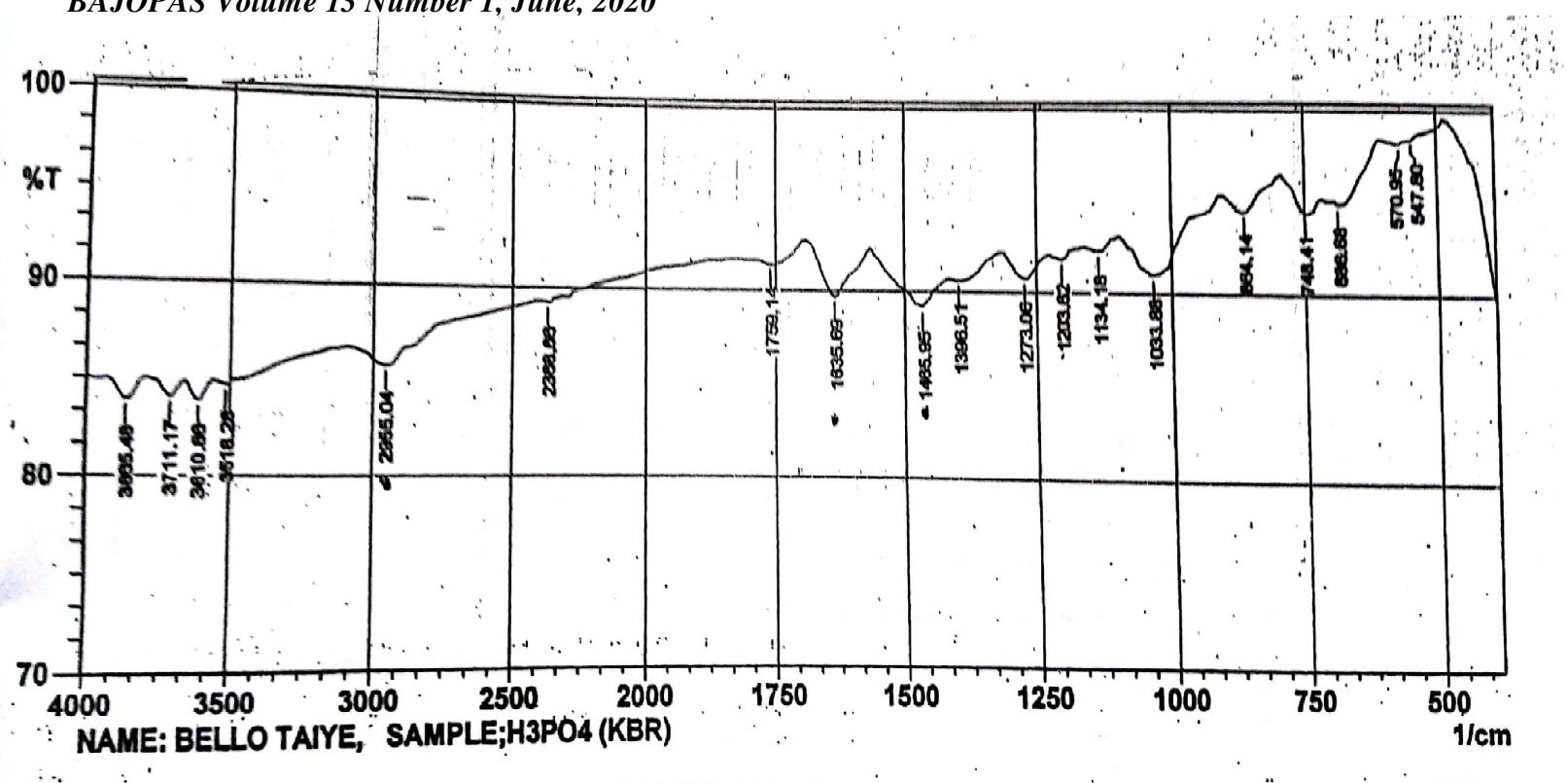

Figure 4: Fourier Transform Infrared Spectroscopy

Effect of Adsorbent Dosage

A series of adsorption experiments were carried out with different adsorption dosages varying from 0.25 to $1.25 \mathrm{~g}$ at initial concentration of $50 \mathrm{ml}$ aliquots of a 100 $\mathrm{mgL}^{-1}$. The effect of carbon dose for the uptake adsorption by activated carbon from black plum was found to decrease by increasing the adsorbent dosage. It was observed that adsorbent dosage of $1 \mathrm{~g}$ has the highest percentage removal and adsorbent dosage of $0.25 \mathrm{~g}$ has the lowest percentage removal as shown in table 3.3 below:

Table 3.3:Result of Effect of Adsorbent Dosage for Chromium (II) ion

\begin{tabular}{llll}
\hline Dosage & $\mathbf{C}_{\mathbf{1}}(\mathbf{m g} / \mathbf{L})$ & $\mathbf{C}_{\mathbf{2}}(\mathbf{m g} / \mathbf{L})$ & Removal (\%) \\
\hline 0.25 & 21.7321 & 15.3479 & 29 \\
0.50 & 26.6517 & 7.3348 & 72.4 \\
0.75 & 41.0051 & 3.9329 & 90.4 \\
1.0 & 41.2602 & 2.8869 & 94 \\
1.25 & 44.3603 & 2.2255 & 93 \\
\hline
\end{tabular}

KEY: $C_{1}=$ initial concentration and $C_{2}=$ final concentration

\section{Effect of pH}

The optimum $\mathrm{pH}$ absorption onto ASCS was found to be 9. pH9it was selected as the optimum value in the $\mathrm{pH}$ range. The sharpest increase in final concentration was observed between $\mathrm{pH} 7$ and 9 . These result show suitability of the adsorbent for the treatment of basic wastewater. It was observed that $\mathrm{pH} 9$ has the highest percentage removal and $\mathrm{pH} 3$ has the lowest percentage removal as shown in table 3.4 below:

Table 3.4: Result of Effect of $\mathrm{pH}$ for Chromium (II) ion

\begin{tabular}{cccc}
\hline $\mathrm{pH}$ & $\mathbf{C}_{\mathbf{1}} \mathbf{( \mathbf { m g } / \mathbf { L } )}$ & $\mathbf{C}_{\mathbf{2}} \mathbf{( \mathbf { m g } / \mathbf { L }}$ & Removal (\%) \\
\hline 3 & 46.7928 & 10.6414 & 22.8 \\
5 & 37.3056 & 12.5388 & 66.3 \\
7 & 26.6372 & 14.2725 & 46.7 \\
9 & 13.3710 & 17.3258 & 78.6 \\
11 & 20.49 & 15.9024 & 22.3 \\
\hline
\end{tabular}

KEY: $C_{1}=$ initial concentration and $C_{2}=$ final concentration 
BAJOPAS Volume 13 Number 1, June, 2020

\section{Effect of Contact Time}

The adsorption on activated carbon prepared from Syzgiumcumini increases with increasing agitation time, it assists to find out the time required for equilibrium attainment for Chromium. The removal rate increase within the first $50 \mathrm{~min}$ then increases rapidly and gradually diminished to attain equilibrium within $60 \mathrm{~min}$ beyond which there was no significant increase in the removal rate. i.e. at $60 \mathrm{~min}$ the adsorption took place. It was observed that contact time of $60 \mathrm{~min}$ has the highest percentage removal and contact time of $10 \mathrm{~min}$ has the lowest percentage removal as shown in table 3.5 below:

Table 3.5: Result of Effect of Contact time for Chromium (II) ion

\begin{tabular}{llll}
\hline Time $(\mathbf{m i n})$ & $\mathbf{C}_{\mathbf{1}}(\mathbf{m g} / \mathbf{L})$ & $\mathbf{C}_{\mathbf{2}}(\mathbf{m g} \mathbf{g} \mathbf{L})$ & Removal \\
\hline 10 & 27.7517 & 14.4496 & 47.9 \\
20 & 30.7227 & 13.8554 & 54.9 \\
30 & 35.7272 & 12.8545 & 64 \\
40 & 41.7413 & 11.798 & 71.2 \\
50 & 45.3063 & 11.6517 & 72 \\
60 & 45.3063 & 10.9387 & 75.8 \\
70 & 45.3063 & 10.9387 & 75.8 \\
80 & 45.3063 & 10.9387 & 75.8 \\
\hline
\end{tabular}

KEY: $\mathrm{C}_{1}=$ initial concentration and $\mathrm{C}_{2}$ = final concentration

\section{CONCLUSION}

The research work investigated the potential of chemically activated carbon of black plum(Syzygiumcumini) seed for the removal of chromium (II) ion from aqueous

\section{REFERENCES}

American Diabetes Association (2009).Standards and medical care in Diabetes 2009. Diabetes ( 32 (supple. 1): 513 - 516.

Bailey, S.E., Olin, T.J., Brick, R.M. and Adrian, D.D.(1999). A review of potentially low cost sorbents for heavy metals. Water Research, 33:2469- 2479

El-Abhar, H.S. and Schaalan M.F. (2014).Phytotherapy in diabetes: Review on potential mechanistics perspectives. World Journal of Diabetes.; 5 (2) : 176 197.

Hui, H., Tang, G. and Govlw.(2009). Hypoglycemic herbs and their action mechanism. Chinese Medicine.,4:11 doi:10.1186/1749-8546-4-11

Lalavani, S.B., Wiltowski, T., Hubner, A., Wetson, A. and Mandich, N. (1998). Uses of Carbon Production: a Review. Renew. Sustain. Energy Rev. 46:218-235.

Mohan, D., and Sing, K.P.(2005). Arsenic removal from water/wastewater using adsorbent - a critical review, Journal of Hazardous Materials, 142:1-53.

Nourbaksh, M.N., Kilicarslan, S., Iihan, S. and Ozdag, H. (2005). Recent advances in solution. The adsorption of Chromium (II) ion onto ASCS was found to be optimum at contact time of $60 \mathrm{~min}$, adsorbent dosage of $1 \mathrm{~g}$ and $\mathrm{pH} 9$.

Application of Activated Carbon from Biowaste for Waste Water Treatment: a Short Review, Journal of cleaner production. 175:361-375.

Ovasif, H., Yousfi, S., Bovamrani, M.L., El kaovali, M., Benmokhtar, S. and Talbi, M. (2013). Removal of a cationic dye from wastewater by adsorption onto natural adsorbents. Journal ofmaterial and Environmental Science 4 :(1) 1 - 10

Ranjan, A., Jaiswal, A. and Raja, R.B. (2011).Enhacementof syzygiumcumini (indianjamun) active constituents by ultra - violet (UV) irradiation method. Journal of Scientific Research and Essays., 6 (12): $2457-2464$.

Schoonen, M.A. and Schoonen, J.M.T.(2014). Removal of crystal violet from aqueous solutions using coal.Journal of colloid and interface science $422: 1-8$

Ulmanu, M., Anger, I., Lakatos, J. and Aurn, G. (2007). Proceeding of the first international conference on environmental research and assessment, Bucharest, Romania, March 23 - 27, pp. $185-192$ 